\title{
原著
}

\section{唾液中の酸産生菌代謝促進因子の bioassay*}

\author{
天 野 文 枝**
}

概要 : 唾液上清中には, 口腔細菌をふくむところの唾液沈渣の, 呼吸および 乳酸発酵を促進する物 質がふくまれており，Hartles らは，これを“Metabolic factor”と名づけた。このものの活性測定 は, 喠液沈渣を用い，主としてWarburg 検圧計による呼吸㧍よび生成した乳酸を， $\mathrm{CO}_{2}$-bicarbonate 緩衝系で， $\mathrm{CO}_{2}$ 量として測定する方法が用いられてきた。しかし，この方法は，操作が煩雑であるな どの欠点をもっているので，多数試料用いるには不適当である。

本研究はここれらの欠点を除いたbioassay 法の開発を目的として行なわれたものである。唾液上清材 料は, Sephadex ゲル滤過によって分画した各フラクションの, 唾液沈渣に対する乳酸発酵促進効果を, Warburg 検圧計によって測定し，その高活性を示すフラクションを合したもの，すなわち，“Metabolic factor"としての活性を示したものが用いられた。

まゔ，Streptococcus 3 種，Lactobacillus 4 種を用いて，発育におよぼす影響を検討し，Str. lactis が著しい活性を示したので, 本菌を唾液沈渣に代換し得る indicator として用い, 濁度法, 酸度滴定法 ならびに，とくに，寒天平板を用いた pulp-disk 法による検定法の諸条件を検討した。

その結果, pulp-disk 法は, 培盖時間の短縮, 多数試料を任意の時期まで安定に保存して測定を行な い得る点で, 他の方法より優れており, 多くの試料についての routine assay として適当である可能性 が認められた。

\section{緒言}

1955年, Hartles ら ${ }^{1)}$ は，口腔細菌叢の呼吸お よび乳酸発醭を促進する物質が，ヒト混合唾液遠 心上清および耳下腺唾液中に存在し, 水溶性, 耐 熱性，透析性のある有機化合物であることを報告 した。このことは, Bramstedt ら (1957) ${ }^{2,3)}$, Kröncke $(1960)^{4)}$, Wasdell $(1960,1962)^{5,6)}$, Beck ら $(1961)^{7}$, 黑沢 $(1961)^{8)}$ によって追試され， この物は，ペプタイドフラクションに関連する物 質であるとされた。さらに, Hartles (1963) ${ }^{9)}$ は, 本活性物質は，口腔細菌叢に対する炭水化物代謝 の補助因子であるとして，この物質を“Metabolic factor"と名づけた。
Kawasaki $(1964)^{101}$ は，Sephadex グル滤過法 によって活性物質を分䧺し，分子量を推定した。 以来, 多くの研究者によって Sephadex ゲル濾過 法が広く用いられるようになった。すなわち， Hay ら $(1965 ， 1966)^{11,12)}$ を初めその他 ${ }^{13-18)}$ によ って, Sephadex ゲル滤過法によって活性部分が 分画され, 活性物質は単一物質ではなく, 高分子 量フラクションおよび低分子量フラクションから なり，低分子量フラクションは，さらに，ペプタ イドおよびアミノ酸を含む混合物からなる多元性 なものであることが報告された。さらに，Hay ら ${ }^{12)} は$ ，この“Metabolic factor”の作用は, 極めて短時間に，口腔細菌叢の代謝を促進するこ とからみて，その作用は口腔細菌の発育に伴うも

* 本論文の要旨は昭和45年 2 月21日第180回東京歯科大学学会において発表した。

** 東京歯科大学口腔衛生学教室（指導：竹内光春教授, 川崎徽講師）

* Department of Preventive Dentistry, Tokyo Dental College. (Directors; Mitsuharu TAKEUCHI, Tohru KAWASAKD

昭和 49 年 9 月 10 日受付 
のではないことを示唆した。

一方，乳酸菌の発育を促進するアミノ酸，アミ ノ酸誘導体，ペプタイド類，蛋白質については数 多くの研究報告 ${ }^{19)}$ があり，とくにアミノ酸扝よび その誘導体に関しては，乳酸菌の栄養要求および 栄養に関連した代謝の研究を背景として，1940年 頃からかなり広範な研究が行なわれ，生化学的作 用等が明らかになり，微生物定量法 (microbiological assay) なども確立されている。

しかし, ペプタイド類, 蛋白質の生化学的作用 および種類等はきわめて複雑であって，いまだじ ゅうぶんに解明されていない。一例として，L. casei の場合, 発育を促進する多数のペプタイド 類は, Strepogenin と総称され, Woolley $ら^{20-29)}$ によって長年にわたる研究成績が 報告されてい る。それによれば， casein の部分加水分解産物中 に，細菌の発育を促進する物質が存在することが 確かめられ，次いで，他の蛋白質の各種酵素によ る分解産物も Strepogenin 供給源になり得るこ とが明らかにされた。このことから Hartles ${ }^{9)}$, Hay ら ${ }^{11)}$ の提唱したところの，発育を伴わない “Metabolic factor”が口腔内常在菌，とくに乳 酸菌の発育に影響を及ぼす factor，すなわち “Growth factor”としても作用する可能性が考 えられる。

従来, 唾液上清中の “Metabolic factor” の活 性度の測定には，主として，Warburg 検圧計を 用いる方法が採用されてきた。この方法は，特殊 な装置を必要とすること, 測定方法自体の煩雑さ に加えて，測定試料の数に限度があり，さらに嫌 気的条件を必要とする場合の反応系内のガス交換 では，当然，ガス交換のための装置とそれに伴う 操作とが要求される。

とくに睡液沈渣を用いて，乳酸発酵促進作用を 測定する場合は，唾液沈渣そのものが不均一で， 不安定であり，同一個人から採取したものであっ ても，採取日時の相異によって，菌叢の組成や量 が変動するため，測定值に再現性がとぼしく，そ の標準化が極めて困難である。

このように, Warburg 検圧計による“Metabolic factor” の活性測定には種々の難点がある
ので，その簡易化，とくに公衆衛生的に，多数の 唾液例について本活性と敬蝕活動性の関連を追求 できるような routine assay の開発が望まれる。

唾液沈渣を用いた場合の諸欠点は，三代らによ っても指摘され, 純培養した Str. salivarius ${ }^{30-32)}$ その他の乳酸菌 ${ }^{33}{ }^{34)}$ を用いて，基礎培地中に産生 される乳酸量を定量することによって，乳酸発酵 の活性度としている。これは， indicator(細菌) の標準化执よび操作の簡易化を意図したものと思 われる。その他, indicator の標準化の例では, Melville ら ${ }^{351}$ によラット口腔分離菌 Streptococcus FA-I を用いた報告, Guggenheim ${ }^{13)} に よ$ る口腔分離菌 Micrococcus luteus を用いた報告が ある。

そこで, 本研究では, 唾液上清中から“Metabolic factor”として分画された代謝促進フラク ションを材料として用い, 各種乳酸菌の発育にお よぼす影響を検討し，その結果適当と思われる乳 酸菌種を選出し, indicator の標準化を図り, 次 いで，この活性を測定し得るような方法の改良と 簡易化について研究し, 若干の知見を得たので報 告する。

\section{研究材料および研究方法}

\section{1. 研究材料}

\section{1 唾液上清材料}

研究に用いた唾液上清材料は，図1に示した Kawasaki ${ }^{101}$ の方法に従って，以下の操作のよう に分画，調製した。

\section{1 .1 唾液の前処理}

齵蝕罹患の著しくない成人の昼食前に採取した 無刺韩混合唾液を用い，採取後直ちに，遠心 $(3,000$ r.p.m., 30min.) して, 唾液上清を得る。唾液上 清は必要になるまで $-20 \sim-25^{\circ} \mathrm{C}$ の氷窒中に凍 結保存する。凍結保存唾液上清を室温で氷解した のち, その $100 \mathrm{ml}$ に対し氷酢酸 $2 \mathrm{ml}$ を滴下して 酸性としたのち，䚓找下にエチルアルコール 200 $\mathrm{ml}$ を徐々に滴下する。滴下後 $5 \sim 6$ 時間室温に放 置して, 生成した白色ないし淡黄色沈溊を遠心 (3,000r.p.m., 30min.) して除去し,その上清を減 圧下 $\left(50 \sim 55^{\circ} \mathrm{C}\right)$ で10 $15 \mathrm{ml}$ になるまで濃縮し 


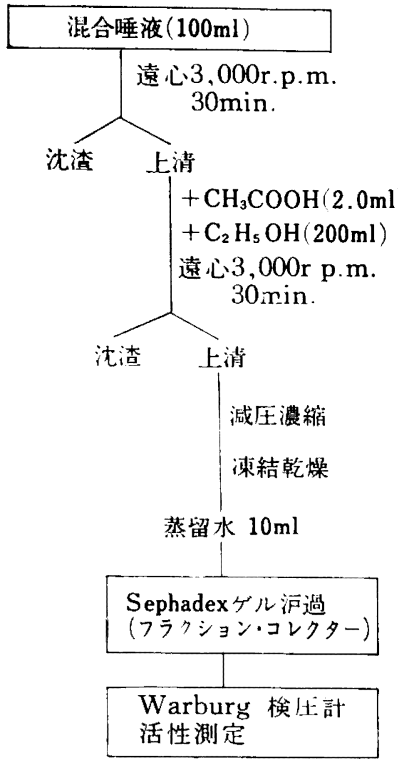

図 1 唾液上清材料の調製法

たのち，凍結乾燥する。得られた凍結乾燥物は， 淡黄色ないし淡黄褐色で，わずかに吸湿性を有し ている。

\subsubsection{Sephadex column による分画材料} あらかじめ，常法 ${ }^{36)}$ に従って前処理調製した Sephadex-G-50（fine）を，内径10mm のクロマ 卜管に充填し，ゲルの長さを $250 \mathrm{~mm}$ とする。 前処理唾液上清の凍結乾燥物を, $2 \mathrm{ml}$ の蒸留 水に溶解させる。この際，微量の不溶物があ れ ば，遠心 (3,000r.p.m., 30min.) して除去したの ち，前記カラム上に添加する。展開溶媒として尔 留水を用い毎分 $0.5 \mathrm{ml}$ の流下速度でゲル濾過を行 ない，溶出液をフラクションコレクターを用いて $4.0 \pm 0.1 \mathrm{ml}$ ずつのフラクションに分画した。

1.1.3 Warburg's manometric method に よる代謝促進効果の測定

前項で得られた各フラクションの代謝促進効果 の 測定は, Kawasaki ${ }^{10)}$, Hartles ${ }^{9}$, Hartles \&

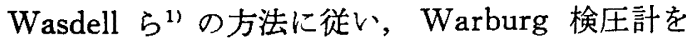
用いて， $\mathrm{CO}_{2}$-bicarbonate 緩衝系，基質にブドウ 糖を用いて行なった。

すなわち，検圧計の主室に，新鮮唾液沈渣傯濁 液 $1.0 \mathrm{ml}$, 前項で得られた各フラクション $1.0 \mathrm{ml}$
（対照は各フラクションの代りに蒸留水 $1.0 \mathrm{ml}$ ）お よび $0.1 \mathrm{M}$ Krebs-Ringer bicarbonate buffer solution $0.25 \mathrm{ml}$, 側室に0.02M glucose solution $0.3 \mathrm{ml}$ を加えたのち, さらに主室に蒸留水を加え て, 容器内液層の全容量を $3.0 \mathrm{ml}$ になるようにし た。ついで, 真空法によって容器内の空気を, $\mathrm{CO}_{2} 5 \%, \mathrm{~N}_{2} 95 \%$ の混合ガスと完全に 置換して 嫌気的条件とし, $37^{\circ} \mathrm{C}$ の恒温浴槽中で 10 分間振 盪して温度平衡を維持したのち, 側室中の glucose solution を注入する。注入後10分間隔で 1 時 間, $\mathrm{CO}_{2}$ 発生量 $(\mu 1)$ を測定し, 1 時間後の $\mathrm{CO}_{2}$ 発生量をもって代謝促進効果の值とした。

このような条件下での代謝促進効果は, 図 2 に 示したパターンとなる。すなわち Fr. No. 9 が最 大值を示し，Fr. No. 10および Fr. No. 8 がこれ に次いで高活性を示している。Fr. No. 3〜7はゅ

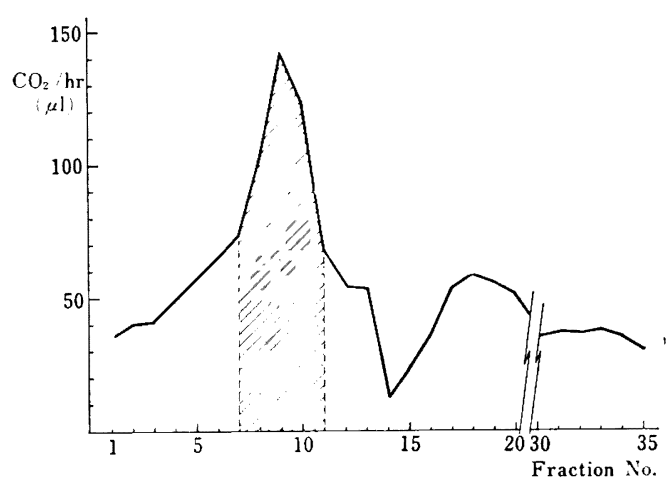

図 2 唓液上清を Sephadex gel filtrationに上っ て分画した各フラクションの唾渡沈渣に対す る代謝促進効果

るやかな上昇傾向を示し，Fr. No. 8〜 Fr. No. 10がピークとなり，Fr. No. 11〜13 および Fr. No. 17〜20はわずかに活性を示している。また， Fr. No. 14および15は, 対照より低活性を示し， 促進作用というよりはむしろ 抑制的に作用してい る。

以上のことから，本研究に用いた喠液上清材料 は, Sephadex column によって分画したフラク ションのうち, 最大活性を示した Fr. No. 9 を中 心に，前後2フラクション，すなわち，Fr. No. $7 \sim$ Fr. No. 11 の溶出部分（図中斜線で示した部 分）を一括して凍結乾燥したもので，以下これを 
唾液上清材料と称し, MF-fraction と略称する。

\section{2 洗浄菌体得濁液}

\section{2 .1 使用菌種}

使用菌種は，下記のような Streptococcus 3 種, Lactobacillus 4 種, 計 7 種で, いずれも東京大学 応用微生物研究所から分与されたものである。

Test microorganism

$\begin{array}{ll}\text { Streptcoccus cremoris } & \text { I A M-1086 } \\ \text { Str. salivarius } & \text { I F O-3350 } \\ \text { Str. lactis } & \text { I A M-1175 }\end{array}$

Lactobacillus acidophilus I A M-1043

L. casei

I AM-1118

L. thermophilus (=ATCC-7469)

L. bulgaricus

I A M-1390

I A M-1120

\section{2 .2 㲘濁液調製}

保存寒天培地 (後出の培地に寒天を加えたもの) に発育したおの㧍のの保存菌株を，移植後 1 週間 以内に，酵母エキス，ペプトン，酢酸ナトリウム， ブドウ 糖をおのおの $1 \%$ 含有する前培養液体培地 （pH 6.8 7.0に調製したのち， $115^{\circ} \mathrm{Cで} 10$ 分間加 圧滅菌したもの） $5 \mathrm{ml}$ 中に接種し， $37^{\circ} \mathrm{C}$ で24時 間培養して前培養菌液とした。この前培養菌液を 無菌的に遠心 (3,000r.p.m., 10min.) して集菌し たのち, 滅菌冷蒸留水で 2 回洗浄, 同様の遠心を 行ない洗浄菌体を得る。これを $5 \mathrm{ml}$ の滅菌蒸留 水に懸濁したものを，洗浄菌体の材料とした。以 下これを，洗浄菌体㲘濁液と称する。

\section{2. 研究方法}

\section{1 濁度法による発育効果検定法}

\section{1 .1 発育試験用培地の調製}

発育試験用基礎培地は，Roberts-Snell ${ }^{37)}$ の完全 合成培地で，その組成は表 1 に示した。これは 2 倍濃度となっている。この基礎培地 $4.0 \mathrm{ml}$ を内径 $20 \mathrm{~mm}$ の比色用試験管 (Erma 製) に分注し, こ れに, MF-fraction を蒸留水に溶解して, 採取時 の量にしたもの $3.0 \mathrm{ml}$ (対照の場合は蒸留水)およ び蒸留水 $1 \mathrm{ml}$ を添加し, 全量を $8.0 \mathrm{ml}$ としたの ち綿栓し, $115^{\circ} \mathrm{C}$ で10分間加圧滅菌したものを, 発育試験用培地とした。各試料ごとにおのおの 2 本の培地を調製した。
表 1 培地組成 (double strength)

\begin{tabular}{|c|c|}
\hline Glucose & $10.0 \mathrm{~g}$ \\
\hline Na-Acetate & $10.0 \mathrm{~g}$ \\
\hline Casamino acid (Vitamin fre & $10.0 \mathrm{~g}$ \\
\hline L-Cystine & $50.0 \mathrm{mg}$ \\
\hline DL-Tryptophane & $50.0 \mathrm{mg}$ \\
\hline Pyridoxine-HCl & $500.0 \mu \mathrm{g}$ \\
\hline Thiamine- $\mathrm{HCl}$ & $250.0 \mu \mathrm{g}$ \\
\hline Riboflavin & $250.0 \mu \mathrm{g}$ \\
\hline Nicotic acid & $250.0 \mu \mathrm{g}$ \\
\hline Ca-D-Pantothenate & $250.0 \mu \mathrm{g}$ \\
\hline $\mathrm{p}$-Aminobenzoic acid & $50.0 \mu \mathrm{g}$ \\
\hline D-Biotin & $2.0 \mu \mathrm{g}$ \\
\hline Folic acid & $1.0 \mu \mathrm{g}$ \\
\hline Adenine & $5.0 \mathrm{mg}$ \\
\hline Guanine & $5.0 \mathrm{mg}$ \\
\hline Uracil & $5.0 \mathrm{mg}$ \\
\hline $\mathrm{KH}_{2} \mathrm{PO}_{4}$ & $1250.0 \mathrm{mg}$ \\
\hline $\mathrm{K}_{2} \mathrm{HPO}_{4}$ & $1250.0 \mathrm{mg}$ \\
\hline Salts solution* & $10.0 \mathrm{ml}$ \\
\hline Aq. dest. & $\begin{array}{c}250.0 \mathrm{ml} \\
(\mathrm{pH} \mathrm{6.8)}\end{array}$ \\
\hline \multicolumn{2}{|l|}{ *Salts solution } \\
\hline $\mathrm{MgSO}_{4} \cdot 7 \mathrm{H}_{2} \mathrm{O}$ & $10.0 \mathrm{~g}$ \\
\hline $\mathrm{MnSO}_{4} \cdot 4 \mathrm{H}_{2} \mathrm{O}$ & $2.0 \mathrm{~g}$ \\
\hline $\mathrm{FeSO}_{4} \cdot 7 \mathrm{H}_{2} \mathrm{O}$ & $0.5 \mathrm{~g}$ \\
\hline $\mathrm{NaCl}$ & $0.5 \mathrm{~g}$ \\
\hline Aq. dest. & \\
\hline
\end{tabular}

\section{1 .2 発育試験法}

発育試験は, 発育試験用培地に洗浄菌体懸濁液 の100倍希釈液を 1 滴ずつ無菌的に 添加したのち, $37^{\circ} \mathrm{C}$ で培養を行ない, 所定の時間間隔で, Erma $\mathrm{N}-5$ 型光電光度計, 波長 $660 \mathrm{~nm}$ を用いて吸光度を 測定し, 各試料の 2 本の平均值をもって発育効果 の值とした。

\section{2 酸度滴定法による発望効果検定法}

前項と同様，基礎培地 $2.0 \mathrm{ml}$ を含む試験管に MF-fraction 溶液 $1.5 \mathrm{ml}$ を加え, さらに蒸留水を

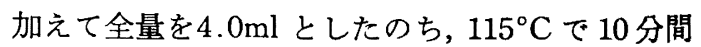
加圧滅菌した。次いで, 洗浄菌体䀣濁液の 100 倍 希釈液を，1滴ずつ無菌的に添加し， $37^{\circ} \mathrm{C}$ で培 養を行なった。所定の時間後に培荃を中止し, 直 ちに沸盪水浴器中に 10 分間浸して反応を停止さ せ，室温に泠却したのち，これに neutral-red・ brom-thymol-blueの等量混合指示薬 $0.45 \mathrm{ml}$ を加 え, $\mathrm{N} / 10-\mathrm{NaOH}$ 溶液で滴定し, その消費量の 2 本の平均值をもって滴定酸度とした。 


\subsection{Pulp-disk 法による発育効果検定法} pulp-disk 法の操作を図 3 に示した。

検定用寒天培地は，前述の Roberts-Snell の基 礎培地に，あらかじめ精製水中で洗浄した寒天 (Bacto-agar, Difco) を，1.0〜1.2\% 濃度になる

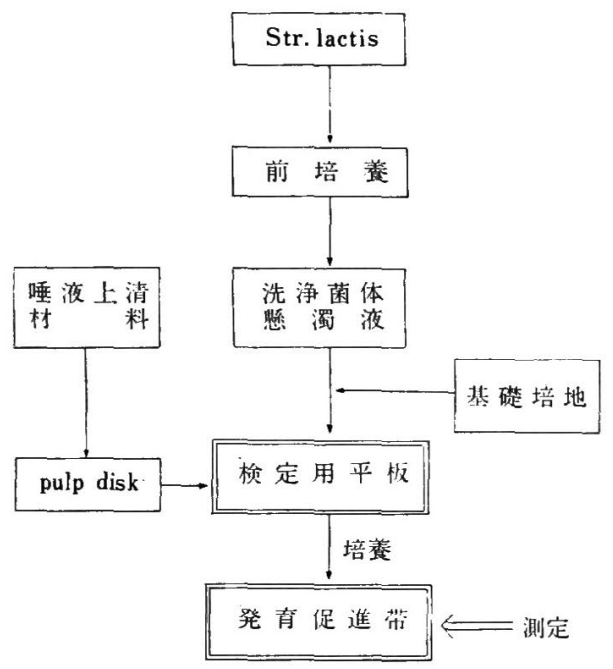

図 3 Pulp-disk 法の操作法

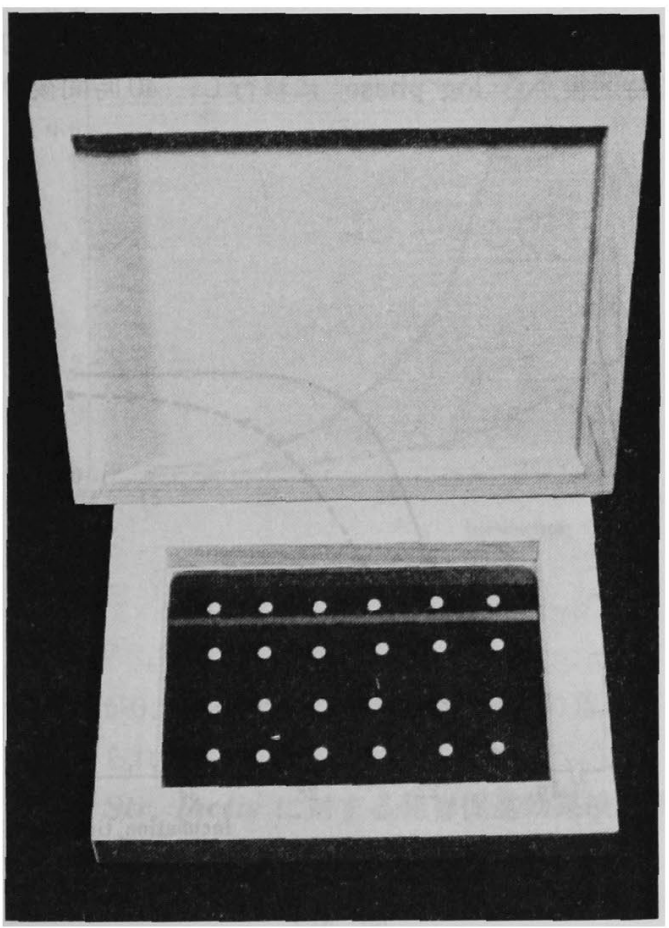

図 4 検定用寒天平板
ように添加し，さらに，蒸留水を加えて，全量を 2 倍としたのち， $115^{\circ} \mathrm{C}$ で 10 分間加圧滅菌した。 これに菌体䀣濁液を，培地 $100 \mathrm{ml}$ に対して $10 \mathrm{ml}$ の割合で添加し，す早く，滅菌ガラス平板上に流し 込み，放冷固化させたものである。 pulp-disk は， 厚さ $0.7 \mathrm{~mm}$ のパルプ（東洋濾紙）を，直径 $6 \mathrm{~mm}$ の円板状に打ち抜いたもので，これを加圧滅菌し たのち乾燥して用いた。

検定方法は，pulp-disk の一端を，被検溶液に 浸け，じゅうぶん液を吸収させたのち，直ちに大 型隇菌濾紙上に 5 秒間置き，過剩溶液を吸収除去 したもの（吸水量 : $12.72 \mu \mathrm{l} / \mathrm{disk}$ )を，検定用寒天 平板上にセットする（図 4)。

これを $37^{\circ} \mathrm{C}$ で20時間以上培養し， disk の周辺 に出現する円形の発育促進帯の直径（長径および 短径の平均值）を，ノギスを用いて計測する。

\section{研 究 成 績}

\section{1. 乳酸菌 7 種に対する発育促進効果}

乳酸菌 7 種に対する発育試験は，培養16時間後 から開始し， 3 時間間隔で 40 時閒後 まで測定し た。成績は表 2 および図 5-1〜7に示したとお りである。図の実線で示した発育曲線は MF. fraction を添加したもので，点線は MF-fraction 無添加の対照である。

この結果, 使用した菌種のうち，L. acidophilus は，MF-fraction を添加しても対照との差異は認 められなかったが，他の菌種はいずれも発育促進 効果が認められた。Str. cremoris, Str. lactis, L. thermophilus, L. casei は, いずれも MF-fraction の添加によって, lag phase の短縮が認められた。 Str. cremoris の場合は，対照は，培養30時間頃か ら log phase に移行しており，MF-fractionの 添加によって， lag phase に約10時間の短縮を示 し，さらに31時間後には， stationary phase に達 している。Str. lactis においては，対照は25時間 後から徐々に緩やかに上昇し，約31時間後から， log phase に移行している。一方, MF-fraction の添加によって，19時間後から log phase に移 行し, lag phaseにおいて約10時間の短縮が認め られた。さらに，40時間後でもなお発育増殖が継 
表 27 種の乳酸菌の発育におよぼす MF-fraction 添加の影瑟

\begin{tabular}{|c|c|c|c|c|c|c|c|c|c|c|}
\hline \multicolumn{2}{|c|}{ 培 養 時 間 } & \multirow{2}{*}{$\begin{array}{c}16 \\
\text { (hrs) }\end{array}$} & \multirow{2}{*}{19} & \multirow{2}{*}{22} & \multirow{2}{*}{25} & \multirow{2}{*}{28} & \multirow{2}{*}{31} & \multirow{2}{*}{34} & \multirow{2}{*}{37} & \multirow{2}{*}{40} \\
\hline 乳酸菌 & & & & & & & & & & \\
\hline Str. cremoris & $\begin{array}{l}\text { cont. } \\
\text { exp. }\end{array}$ & $\begin{array}{l}0.005 \\
0.020\end{array}$ & $\begin{array}{l}0.007 \\
0.033\end{array}$ & $\begin{array}{l}0.007 \\
0.095\end{array}$ & $\begin{array}{l}0.006 \\
0.255\end{array}$ & $\begin{array}{l}0.015 \\
0.454\end{array}$ & $\begin{array}{l}0.050 \\
0.635\end{array}$ & $\begin{array}{l}0.064 \\
0.651\end{array}$ & $\begin{array}{l}0.330 \\
0.653\end{array}$ & $\begin{array}{l}0.625 \\
0.652\end{array}$ \\
\hline Str, salivarius & $\begin{array}{l}\text { cont } \\
\text { exp. }\end{array}$ & $\begin{array}{l}0.010 \\
0.124\end{array}$ & $\begin{array}{l}0.045 \\
0.205\end{array}$ & $\begin{array}{l}0.163 \\
0.374\end{array}$ & $\begin{array}{l}0.344 \\
0.605\end{array}$ & $\begin{array}{l}0.502 \\
0.664\end{array}$ & $\begin{array}{l}0.600 \\
0.682\end{array}$ & $\begin{array}{l}0.625 \\
0.680\end{array}$ & $\begin{array}{l}0.655 \\
0.682\end{array}$ & $\begin{array}{l}0.657 \\
0.684\end{array}$ \\
\hline Str. lactis & $\begin{array}{l}\text { cont. } \\
\text { exp. }\end{array}$ & $\begin{array}{l}0.006 \\
0.032\end{array}$ & $\begin{array}{l}0.013 \\
0.056\end{array}$ & $\begin{array}{l}0.022 \\
0.125\end{array}$ & $\begin{array}{l}0.038 \\
0.266\end{array}$ & $\begin{array}{l}0.052 \\
0.538\end{array}$ & $\begin{array}{l}0.110 \\
0.693\end{array}$ & $\begin{array}{l}0.125 \\
0.755\end{array}$ & $\begin{array}{l}0.348 \\
0.832\end{array}$ & $\begin{array}{l}0.605 \\
0.874\end{array}$ \\
\hline L. acidophilus & $\begin{array}{l}\text { cont. } \\
\text { exp. }\end{array}$ & $\begin{array}{l}0.008 \\
0.020\end{array}$ & $\begin{array}{l}0.017 \\
0.051\end{array}$ & $\begin{array}{l}0.032 \\
0.068\end{array}$ & $\begin{array}{l}0.045 \\
0.095\end{array}$ & $\begin{array}{l}0.090 \\
0.194\end{array}$ & $\begin{array}{l}0.205 \\
0.304\end{array}$ & $\begin{array}{l}0.520 \\
0.558\end{array}$ & $\begin{array}{l}0.714 \\
0.722\end{array}$ & $\begin{array}{l}0.738 \\
0.728\end{array}$ \\
\hline L. casei & $\begin{array}{l}\text { cont. } \\
\text { exp. }\end{array}$ & $\begin{array}{l}0.005 \\
0.016\end{array}$ & $\begin{array}{l}0.006 \\
0.030\end{array}$ & $\begin{array}{l}0.025 \\
0.055\end{array}$ & $\begin{array}{l}0.040 \\
0.098\end{array}$ & $\begin{array}{l}0.042 \\
0.180\end{array}$ & $\begin{array}{l}0.056 \\
0.311\end{array}$ & $\begin{array}{l}0.092 \\
0.598\end{array}$ & $\begin{array}{l}0.153 \\
0.710\end{array}$ & $\begin{array}{l}0.205 \\
0.767\end{array}$ \\
\hline L. thermophilus & $\begin{array}{l}\text { cont. } \\
\text { exp. }\end{array}$ & $\begin{array}{l}0.004 \\
0.021\end{array}$ & $\begin{array}{l}0.005 \\
0.045\end{array}$ & $\begin{array}{l}0.010 \\
0.054\end{array}$ & $\begin{array}{l}0.022 \\
0.265\end{array}$ & $\begin{array}{l}0.045 \\
0.578\end{array}$ & $\begin{array}{l}0.073 \\
0.668\end{array}$ & $\begin{array}{l}0.396 \\
0.687\end{array}$ & $\begin{array}{l}0.665 \\
0.667\end{array}$ & $\begin{array}{l}0.672 \\
0.665\end{array}$ \\
\hline L. bulgaricus & $\begin{array}{l}\text { cont. } \\
\text { exp. }\end{array}$ & $\begin{array}{l}0.004 \\
0.008\end{array}$ & $\begin{array}{l}0.004 \\
0.015\end{array}$ & $\begin{array}{l}0.006 \\
0.097\end{array}$ & $\begin{array}{l}0.006 \\
0.200\end{array}$ & $\begin{array}{l}0.012 \\
0.351\end{array}$ & $\begin{array}{l}0.082 \\
0.557\end{array}$ & $\begin{array}{l}0.174 \\
0.615\end{array}$ & $\begin{array}{l}0.512 \\
0.645\end{array}$ & $\begin{array}{l}0.618 \\
0.650\end{array}$ \\
\hline
\end{tabular}

表中の数字は波長 $660 \mathrm{~nm}$ に㧍ける吸光度

続しており，培羡 40 時間後の吸光度が 0.874 で, 使用乳酸菌中最大值を示している。

レンサ球菌群で認められた lag phase の短縮 は, 乳酸桿菌群でも同様に観察された。すなわち L. thermophilusでは，対照は，28時間後から log phase に移行し，37時間後に stationary phase に達しているが，MF-fraction 添加によって，22 時間後から log phase に移行し, lag phaseにお

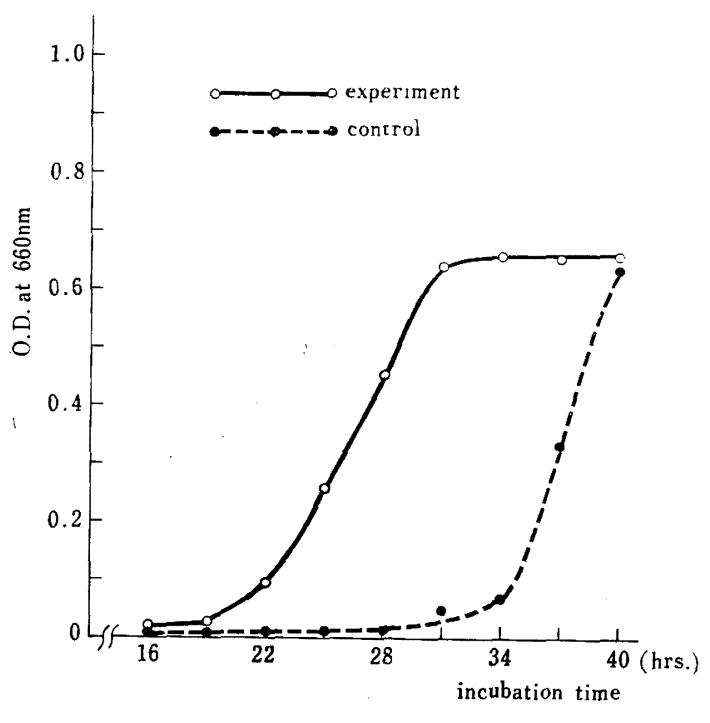

Str. cremoris

図 5-17種の乳酸菌の発㕕(波長660nmにおける吸 光度）におよぽすMF-fraction 添加の影響
いて約 6 時間の短縮を示し,さらに, 31 時間後で stationary phase に達している。L. casei では, とくに対照との差が著しく現われている。すなわ ち, L. casei は他の乳酸菌と比較して, 本培地に おける発育増殖が著しく不良で, 培養40時間後で も吸光度が 0.205 で, 使用乳酸菌中最低值を示し ている。一方, MF-fraction の添加によって, 約 22時間後から $\log$ phase に移行し，40 時間後の

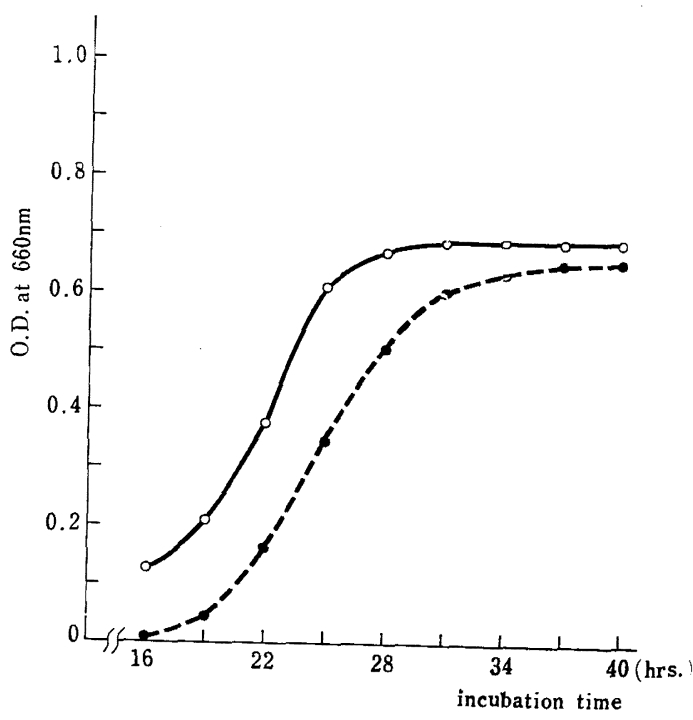

Str. salivarius

图 5-2 


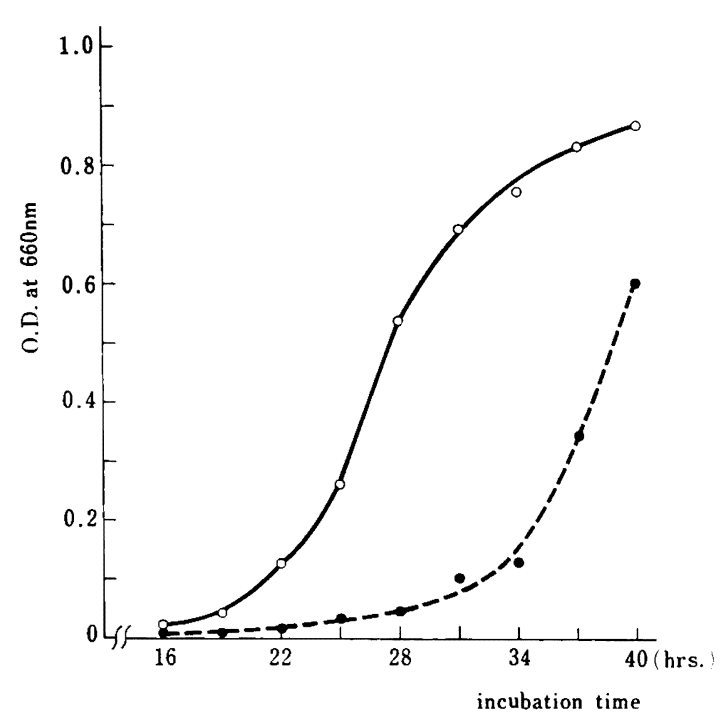

Str. lact is

图 5-3

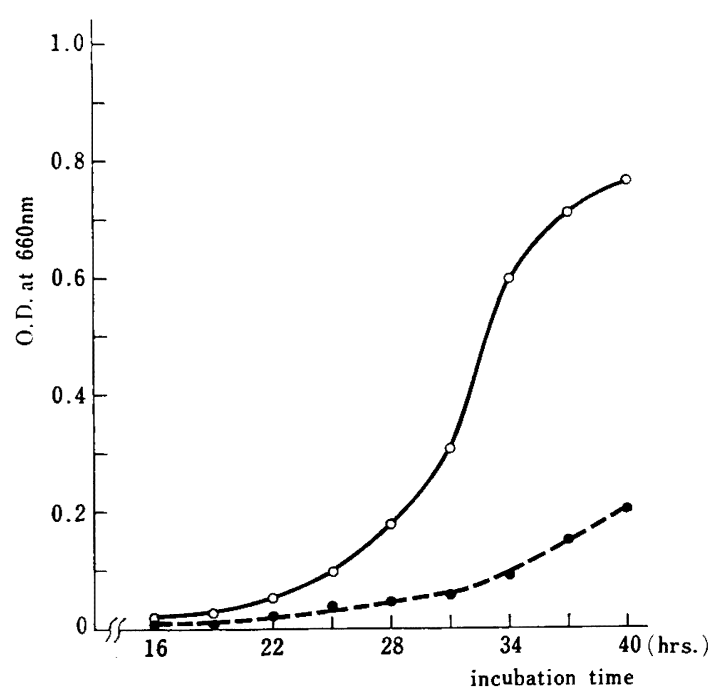

L. casei

吸光度が0.767を示して, 対照との発育の差が明確 に認められた。

\section{Str. lactis に対する発育促進効果検定法}

\section{1 濁度法}

使用菌種は, 前項 1 の研究で使用した 7 種の菌 種のうち, MF-fraction 添加によって発育効果が

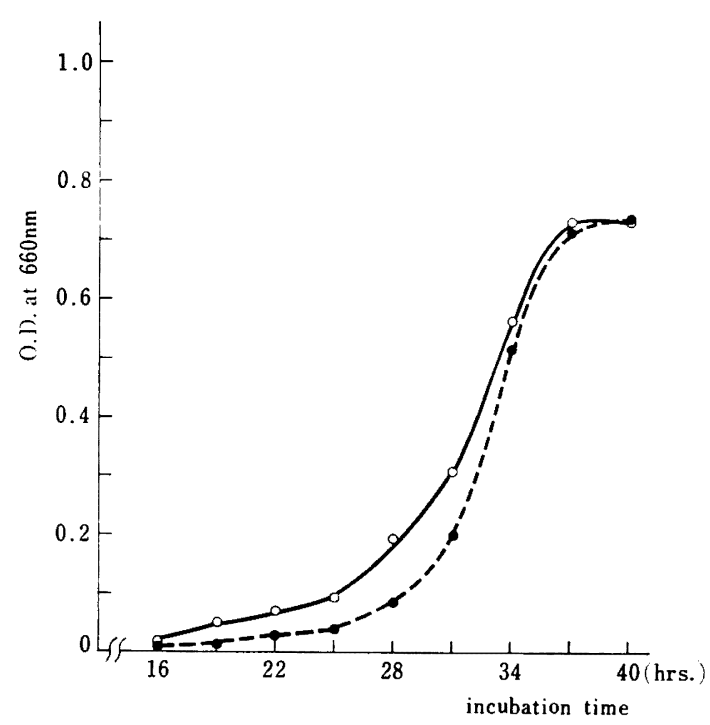

L. acidophilus

图 5-4

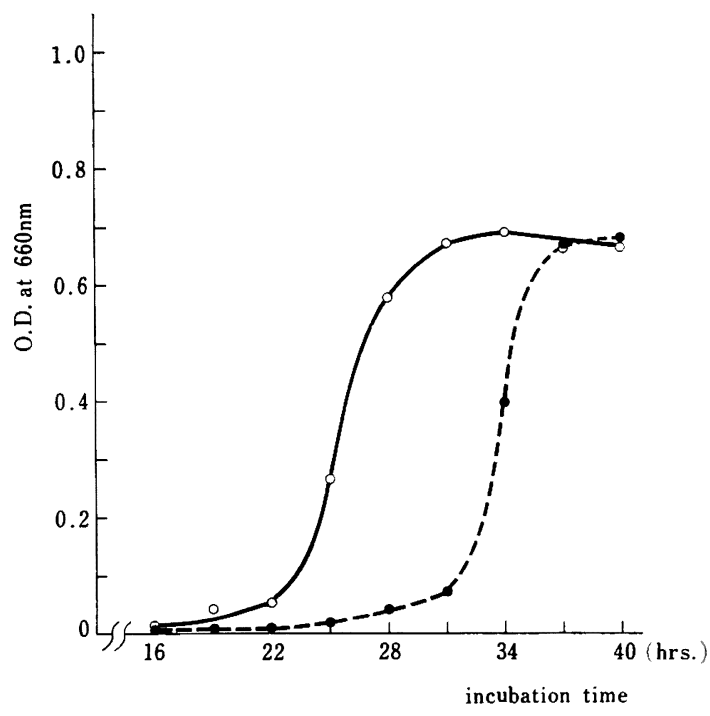

L. thermophilus

図 5-6

最も良好と認められた Str. lactis を使用した。

MF-fraction を蒸留水に溶解し, 唾液採取時の 量にしたものを，濃度 1 とし，これをさらに，濃 度 $1 / 2,3 / 8,1 / 4,1 / 8,1 / 20,1 / 30,1 / 40$ となるように, 蒸留水で段階希釈した希釈試料を用いた。

各希釈試料 $3.0 \mathrm{ml}$ を, 前述した基礎培地 $3.0 \mathrm{~m}$ 


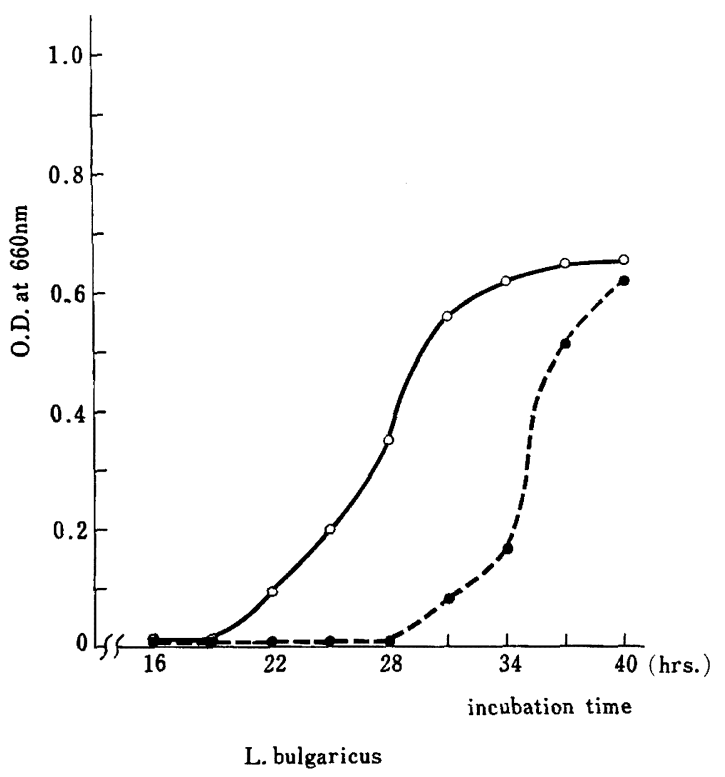

図 5-7

を含む比色用試験管に添加したのち，加圧滅菌 し, 以下, 研究方法 2.1 で述べた 発育効果検定法 に従って，濁度を測定した。培養開始 20 時間後か ら，3 時間間隔で吸光度を測定した 結果を，表 3 に示した。

表 3 Str. lactis の発育におよぼす MF-fraction の添加濃度の影響 (濁度法)

\begin{tabular}{l|c|c|c|c}
\hline $\begin{array}{c}\text { MF-fraction } \\
\text { 添加濃度 }\end{array}$ & \multicolumn{4}{|c|}{ 培 時 間 (hrs.) } \\
\cline { 2 - 5 } & 20 & 23 & 26 & 29 \\
\hline $1 / 2$ & 0.110 & 0.250 & 0.503 & 0.740 \\
$3 / 8$ & 0.048 & 0.125 & 0.267 & 0.560 \\
$1 / 4$ & 0.028 & 0.061 & 0.128 & 0.278 \\
$1 / 8$ & 0.017 & 0.031 & 0.055 & 0.133 \\
$1 / 20$ & 0.009 & 0.016 & 0.024 & 0.039 \\
$1 / 30$ & 0.006 & 0.013 & 0.015 & 0.028 \\
$1 / 40$ & 0.001 & 0.009 & 0.011 & 0.026
\end{tabular}

表中の数字は波長 $660 \mathrm{~nm}$ に㧍ける吸光度

29 時間培養では, 添加 MF-fraction の添加濃 度 $1 / 30$ 以下でも，ある程度の発育促進効果が現わ れている。

また, $1 / 2 \sim 3 / 8$ の高濃度の場合には, さらに著 しい促進効果が現われている。図 6 注各培羕時間 における，吸光度と添加 MF-fraction の添加濃

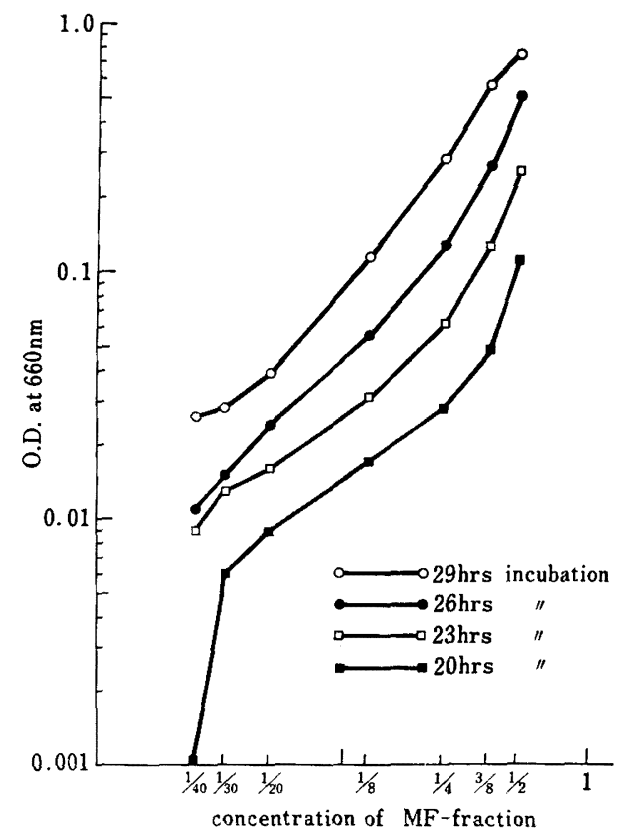

図 6 各培㙚時間における MF-fraction 添加浱度 と Str. lactis の発育（波長660nm における 吸光度）との関係

度とを，両対数グラフ上にプロットしたものであ る。培養時間の延長と共に直線性となる傾向が 認められた。また, 培養20時間では, 添加濃度 ${ }^{1 / 2}$

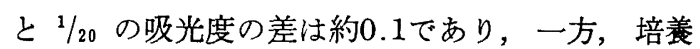
29 時間では, 両者の吸光度の差は約 0.7 であった。 また, この間の添加濃度 $3 / 8,1 / 4,1 / 8$ の吸光度の 值は， $1 / 2$ と $1 / 20$ 濃度の値を結ぶ直線上に位置し ていることが認められた。

同様に図 7 は, MF-fraction の各添加濃度にお ける，培養20時間から29時間までの発育曲線を示 したものである。 $1 / 20$ 以上の 添加濃度では, いず れの濃度もほぼ同程度の直線的な上梨傾向を示し ている。

\section{2 酸度滴定法}

使用菌種および MF-fraction の希橎試料は, 前 項の濁度法と同様のものを用いた。濁度法による 測定結果から, 添加 MF-fraction による発育の 差が，最も著しい培養29時間後に，N/10-NaOH による滴定を行なった。

結果は, 表 4, 図 8 のようである。添加 MF. fraction $91 / 8 \sim 1 / 2$ 濃度の範囲で, 各測定値はほ 


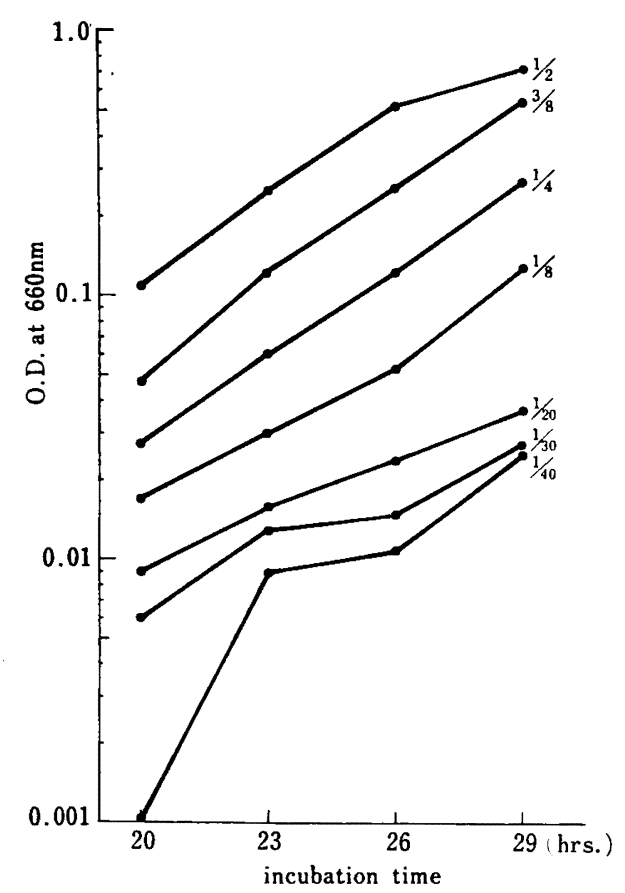

图 7 MF-fraction の各添加䈨度における培養時間 と Str. lactis の発育（波長660nm における 吸光度）との関係

表 4 培養 29 時間後の Str. lactis の酸産生にお よぼす MF-fractionの添加笠度の影響 (酸度滴定法)

\begin{tabular}{c|c}
\hline $\begin{array}{c}\text { MF-fraction } \\
\text { 添加灌度 }\end{array}$ & $\begin{array}{c}\text { 滴 定 酸 度 } \\
(\mathrm{N} / 10-\mathrm{NaOH} \text { の } \mathrm{ml})\end{array}$ \\
\hline $1 / 2$ & 2.49 \\
$3 / 8$ & 1.80 \\
$1 / 4$ & 1.13 \\
$1 / 8$ & 0.64 \\
$1 / 20$ & 0.59 \\
$1 / 30$ & 0.53 \\
0 & 0.41
\end{tabular}

ぼ直線上に位置することが認められた。

\subsection{Pulp-disk 法}

pulp-disk 法が MF-fraction の検定に適応し得 るか否かについて，以下述べる検定条件を設定

し, 発育促進帯の形状を観察した。

\subsection{1 接種菌濃度の影響}

使用菌種は，前項同様 Str. lactis を用いた。研 究材料1.2に従って調製した Str. lactis の洗浄菌

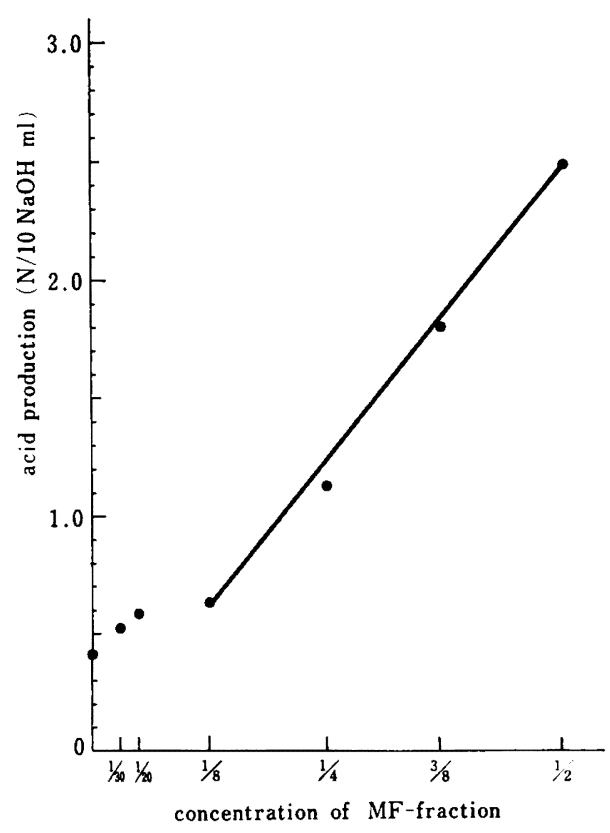

図 8 Str. lactis の酸産生量と MF-fraction の添 加浱度との関倸（酸度滴定法）

体彩濁液の菌濃度を 1 とし，これをさらに，菌濃 度 $1 / 2,1 / 5,1 / 10,1 / 50,1 / 100$ となるように希釈した 菌体㲘濁液を用い，発育促進帯の形状を観察し た。その結果, 菌濃度 $1 / 50$ および $1 / 100$ では, disk 周辺に菌の発育は認められなかった。また, 菌濃度 1 および $1 / 2$ では, 平板全面に菌が発育し, back ground と発育促進帯との判別ができなかっ た。

一方, 菌濃度 $1 / 5$ および $1 / 10$ では培養後約 20 時 間で, disk周辺に発育促進帯が出現した(図 9-1), 2)）。しかし，この場合でも培養を継続した 26 時 間後の観察では, 平板全面に菌が発育し, 発育促 進帯との判別が不可能となった（図 9-3），4））。 また, この両濃度の発育促進帯の形状を比較する と, 菌濃度 $1 / 5$ の方がやや良好と認められたが, 周縁の境界線は不明確であった。

\section{3 .2 寒天濃度の影響}

検定用培地に添加する寒天濃度を, 培地に対し て，0.5\%，1.0\%，1.5\%，2.0\%となるように調 製した平板を用い，菌濃度 $1 / 5$ の条件で，培盖 20 時間後に出現する発育促進帯の 形状を観察した。 その結果, 寒天濃度が高くなるに従って, 発育促 


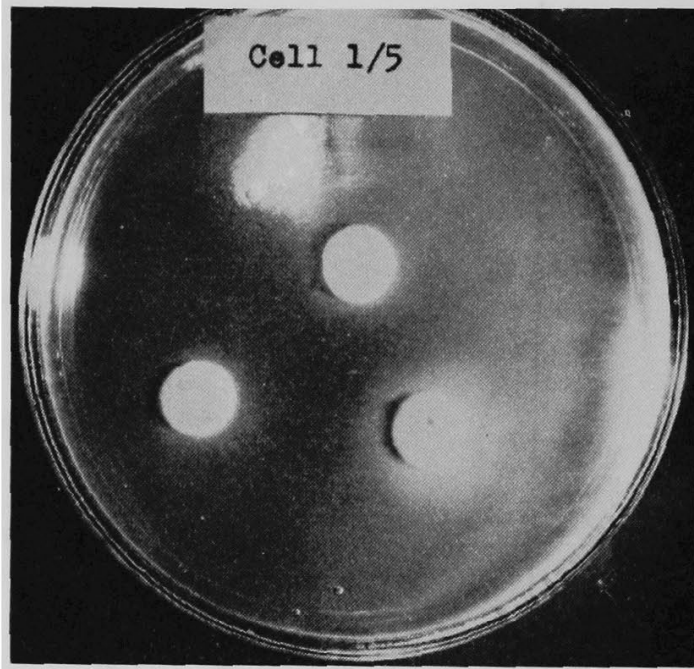

1) 接種菌濃度 $1 / 5$, 培養20時問後の発育促進帯

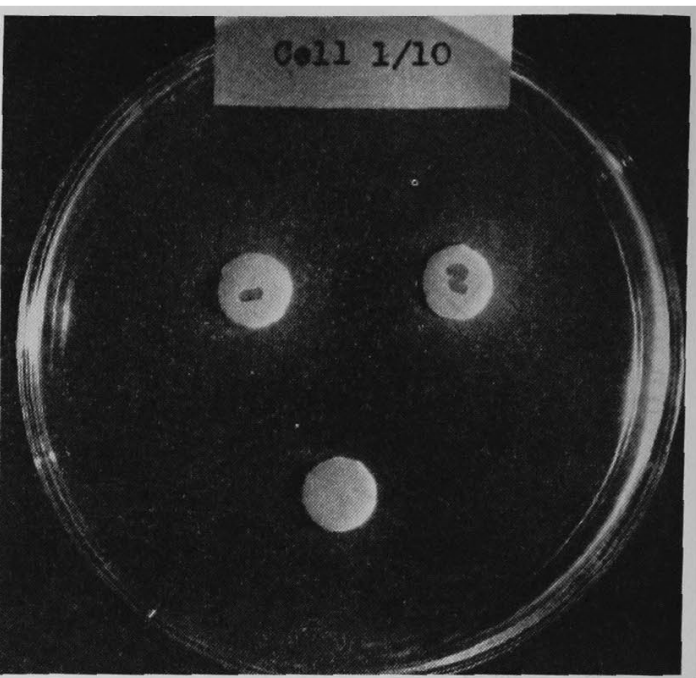

2) 接種菌濃度 $1 / 10$, 培養 20 時間後の発育促進带

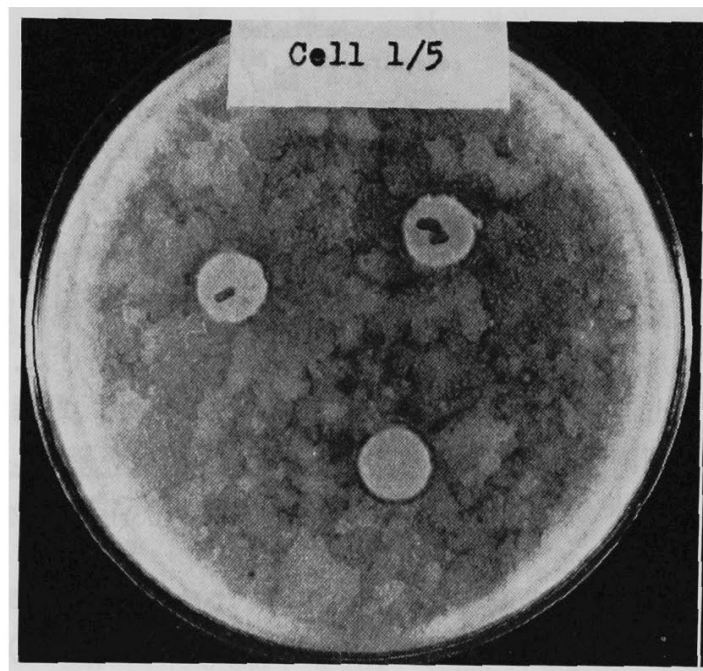

3）接種菌濃度 $1 / 5$, 培養 26 時間後に平板全面に 発育した菌体

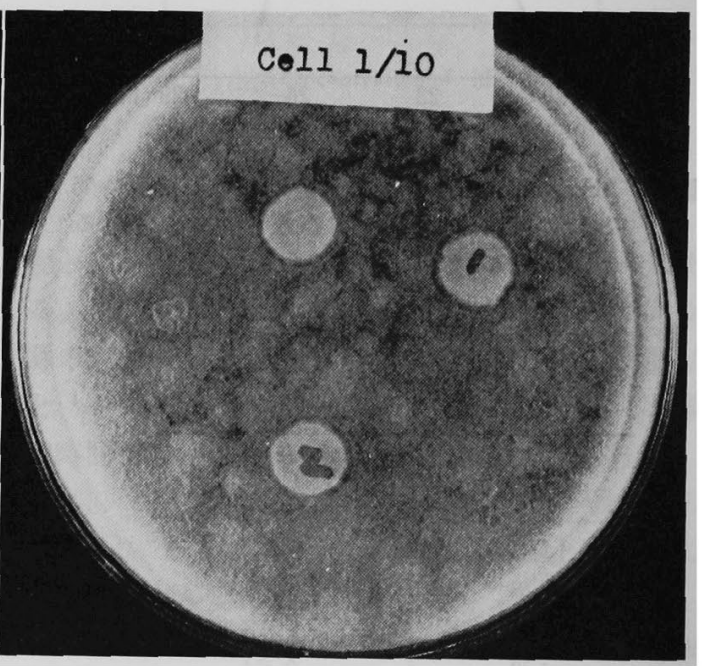

4) 接種菌濃度 $1 / 10$, 培養 26 時間後に平板全面に 発育した菌体

図 9 Pulp-disk 法における，Str. lactis の発育促進帯におよぼす接種菌濃度と培養時閒の影響

進帯は，やや小さくなる傾向が認められたが，周 緑部の境界線の明確度には変化がなく，また， $0.5 \%$ では操作上難点があった。

\section{3 .3 食塩添加の影響}

検定用培地に，20\%食塩溶液を添加し，最終食 塩濃度が $0.1 ， 0.5,0.7,1.0,1.2,1.5,2.0 \%$ になるように調製したのち，菌濃度を $1 / 5$ とし て, 培養20時間後の発育促進帯の 形状を 観察し た。
その結果, 食塩濃度の増加とともに, 発育促進 帯は小さくなるが, 周縁部の境界線が明確になる 傾向を認めた。しかし, 1.5\%, 2.0\%のように高濃 度の食塩添加では, 菌の発育が著しく阻止され た。この場合, 培養時間を, さらに延長すると, 発育促進帯は出現したが直径は小さくなった。

\section{3 .4 水室保存の影響}

本項では，発育促進带を大きくするために，氷 室保存の影響について検討した。すなわち，常法 
に従って, 試料を吸収させた pulp-disk を, 寒天 平板上にセットしたのち，ただちに， $5^{\circ} \mathrm{C}$ の水室 中に一定時間放置して試料の拉散を促し, その後 培養を行なって, 発育促進帯の形状を観察した。 その結果， 2 時閒保存のものは，直径は大きくな るが，周縁部の境界線は，やや不明確になる傾向 が認められた。さらに保存時間を延長すると試料 濃度が希薄となり, 発育促進帯の判別が不明確に なる傾向が認められた。

\subsection{5 $\mathrm{pH}$ 指示薬添加の影響}

検定用培地に前もって, methyl-red の $2 \%$ ア ルコール溶液を， $2 \%$ の割合で添加して培養を行 ない，出現する発育促進帯の形状および色調変化 を観察した。その結果, back ground は淡黄色で 透明であるが，菌の発育促進带とその外縁部に広 がる淡紅色の変色帯を認めたが，この変色帯の境 界線は，不明確であった。

\section{3 .6 試料 $\mathrm{pH}$ の影響}

MF-fraction の凍結乾燥物を, 蒸留水に溶解し たのち, $\mathrm{N} / 10-\mathrm{NaOH}$ 溶液抢よび $\mathrm{N} / 10-\mathrm{HCl}$ 溶 液を用いて， $\mathrm{pH}$ を1.0，2.0，3.0，4.0，5.0， $6.0 ， 7.0 ， 7.6$ に調製した試料溶液を用い，菌濃 度 $1 / 5$, 食塩濃度 $1.0 \%$, 培養 20 時間の条件で, 出 現する発育促進帯の形状を観察した。

その結果は, 図10に示したとおりである。 $\mathrm{pH}$ 6.0 から pH 7.6の間では発育促進帯の出現はな

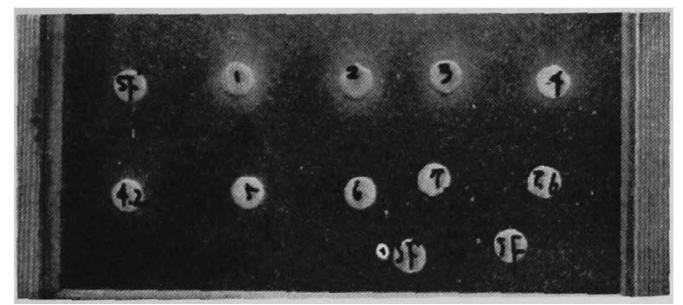

図 10 Pulp-disk 法に拈ける発育促進带におょほ す試料 $\mathrm{pH}$ の影響

disk 上の数字はそれぞれの試料の $\mathrm{pH}$ 京 于

く, $\mathrm{pH} 7.0,7.6$ ではむしろ発育阻止帯が認めら れた。pH 5.0では，わずかに発育が認められた が, 周縁部はかなり不明確であった。 $\mathrm{pH} 2.0$ か $5 \mathrm{pH} 4.2$ 間では, 明確な発育促進帯が出現し, $\mathrm{pH}$ の上昇と共に直径が大きくなる傾向が認めら
れた。

さらに，試料 $\mathrm{pH}$ を2.0から0.4間隔で，4.8ま で調製した 8 種の試料溶液について, 発育促進帯 の出罖状態を観察した結果， $\mathrm{pH} 2.0 \sim 4.4$ のもの では, 発育促進帯の周縁部がかなり明確であ。 た。また， $\mathrm{pH}$ の上昇とともに，わずかに発育促 進帯が大きくなる傾向を示し, $\mathrm{pH} 4.0$ 扔上び 4.4 で最大值を示した。

\subsubsection{Pulp-disk 試料の乾燥の影響}

MF-fraction を吸收させた pulp-disk の, 保存 性について検討した。

すなわち, 本法の操作に従って, MF-fraction を disk に吸収させ, 直ちに凍結乾燥したのち, 水室中に，2，4，6，10，20 日間保存した 乾燥 pulp-disk 試料を用いて，次に述べる disk 試料 について, 発育促進帯の形状を観察した。

すなわち，(1)：各期間保存した乾燥 disk 試料 をそのまま, (2)：(1)の各乾燥 disk 試料に, マイ クロシリンジ（仁丹テルモ）を用いて $15 \mu \mathrm{l}$ の蒸留 水を吸収させたもの, (3): MF-fraction 溶液に disk を浸漬して，所定量を吸収させたもの，を用 いて, 同一の検定用平板にセットして, 培羕20時 間後の発育促進帯の形状を観察した。その結果, いずれの場合も, 同程度の発育が認められ, 発育 促進帯の形状および直径に変化が見られなかっ た。

\subsubsection{MF-fraction 濃度の影響}

MF-fraction の凍結乾燥粉末 $20 \mathrm{mg}$ を蒸留水 1 $\mathrm{ml}$ に溶解したもの拉よびこれを $0.05 \mathrm{mg} / \mathrm{ml}$ まで 段階希釈した 9 試料を, $\mathrm{N} / 10-\mathrm{HCl}$ を用いて, $\mathrm{pH}$ 4.4 に調製したのち，菌濃度 $1 / 5$, 食塩添加量 $1.0 \%$ の条件下で培養20時間後の発育促進帯の直径を計 測した。その結果は，表 5 および図11に示したと おりである。表中の（）呙の数字は, pulp-disk に吸収された乾燥 MF-fractionの $\mu \mathrm{g}$ 数を示し たものである。 $0.25 \mathrm{mg} / \mathrm{ml}(3.2 \mu \mathrm{g} / \mathrm{disk})$ 以上の ものが計測可能であり， $0.1 \mathrm{mg} / \mathrm{ml}(1.3 \mu \mathrm{g} / \mathrm{disk})$ では，わずかに発育促進帯を認めたに過ぎない。 図11では，試料濃度 $0.25 \sim 5.0 \mathrm{mg} / \mathrm{ml} \quad(3.2 \mu \mathrm{g} \sim$ $63.8 \mu \mathrm{g} / \mathrm{disk})$ の範囲の值が, 直線性を示した。 
表 5 Pulp-disk 法に抢ける MF-fractionの各 添加灌度ごとの発育促進带の直径

\begin{tabular}{cc|c}
\hline $\begin{array}{c}\text { MF-fraction } \\
\mathrm{mg} / \mathrm{ml}\end{array}$ & $\begin{array}{c}\text { 添加濃度 } \\
(\mu \mathrm{g} / \mathrm{disk})\end{array}$ & $\begin{array}{c}\text { 直 径 } \\
\mathrm{mm}\end{array}$ \\
\hline 20.0 & $(255.0)$ & 28.1 \\
10.0 & $(127.5)$ & 27.3 \\
5.0 & $(63.8)$ & 26.2 \\
2.5 & $(31.9)$ & 22.9 \\
1.0 & $(12.8)$ & 19.7 \\
0.5 & $(6.4)$ & 16.5 \\
0.25 & $(3.2)$ & 12.3 \\
0.10 & $(1.3)$ & $(6.9)^{*}$ \\
0.05 & $(0.6)$ & -
\end{tabular}

*発育が不良でわずかに発育促進带を認めたにすぎな い。したがって計測値は不確実である。

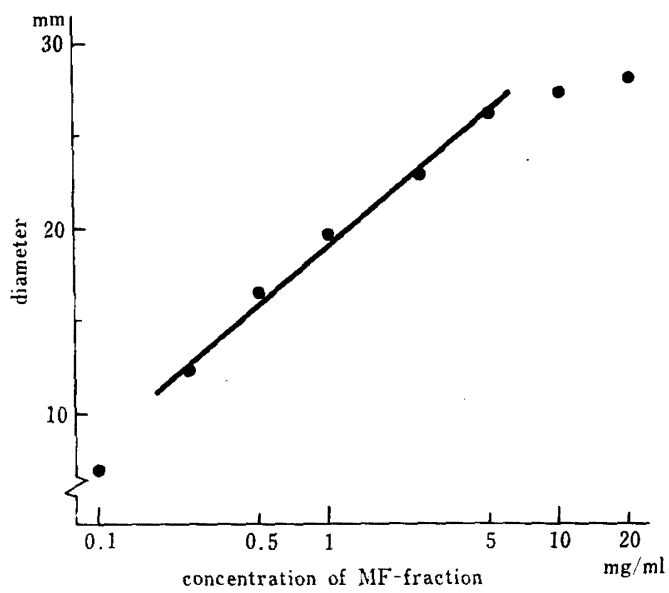

図 11 Pulp-disk 法に拈ける MF-fraction の添加

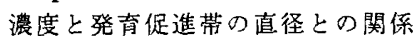

\section{考察}

\section{1. 唾液上清材料について}

本研究で用いられた唾液上清材料は，Kawasa$\mathrm{ki}^{10)}$ の方法に従い，Sephadex ゲル濾過法によっ て分離した MF-fraction である。ここで得られ た活性フラクションは，研究材料1.1.3で述心らられ たように，口腔細菌叢を含む唾液沈渣に対する酸 産生菌代謝促進因子を Warburg 検圧計により， 測定して得られたもので, Hartles" が提唱した， いわゆる菌の発育を伴わない“Metabolic factor”の分離を目的として唾液から分画され たものである。しかし，研究成績 1 で明らかなよ
うに, MF-fraction は乳酸菌に対して 発育促進 作用をも示すこと，すなわち, “Growth factor” としても作用することが認められる。

このことから次の事項が 推定できる。すなわ ち，(1) “Metabolic factor”として作用する活 性物質が同時に“Growth factor”としても作 用する場合，(2) “Metabolic factor”として作 用する物質と “Growth factor” として作用す る物質とが，MF-fraction 中に共存した場合であ

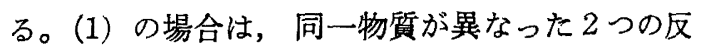
応系で，それぞれ異なった作用を現わしたもので あるから，いずれの作用を測定しても，その物質 の測定法として採用し得る。(2) の場合は，同一 フラクションに異なった物質が共存したことにな るから，䉷密には，それぞれの物質に適応した異 なった測定法によらなければならない。しかし， この 2 つの物質が常に同一割合で 共存する混合物 である場合には，一方の作用を測定することによ って，他方の量を推定できるから，異なる物質の 測定法となり得る可能性も考えられる。

しかるに，本研究で用いられた MF-fraction には, Sephadex column 上で極めて類似した性 状を示す物質が存在し，この物質が乳酸菌の発育

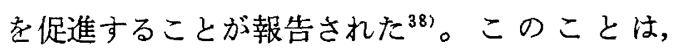
（2）の事項を支持するものであり，本研究で用い た MF-fraction の分離方法を用いる限りでは, 両物質の共存は不可避である。

MF-fraction 中に含まれる両物質の量的な関係 は今後の研究に待たねばならないが，もし，量的 に相関があるとすれば，本研究で 種々検討され た発育促進作用の測定法をもって，“Metabolic factor”の間接測定法とすることが可能と考えら れる。

一方, 研究材料 1.1.3 の Warburg 検圧計で “Metabolic factor”を分離する場合の反応系 は，栄養的にも，時間的にも菌の発育法えられ ない。しかも $\mathrm{CO}_{2}$-bicarbonate 緩衝系内は, $\mathrm{pH}$ 7.4である。この $\mathrm{pH}$ 条件は, 研究成績 2.3.6の “Growth factor”の至適 $\mathrm{pH}$ からみれば，必ず しも满足な条件ではなく，むしろ，不適当な条件 と思われる。したがって，このような反応条件下 
では, “Growth factor” の作用が masking さ れた状態で，乳酸発酵促進作用のみが発現したと 推察される。また，本研究における菌の発育測定 の反応系では，使用培地が完全合成培地であり， しかも，20 時間以上の培養が行なわれている。 このような条件下では，培養の初期において， “Growth factor” の作用はある程度 maskingさ れた状態であって，“Metabolic factor”による 乳酸発酵促進作用が，まず先行することが考えら れ，次いで，ここで産生された乳酸（産生有機酸 すべてを含む)によって反応系の $\mathrm{pH}$ が低下し，

“Growth factor” の至適 $\mathrm{pH}$ に近づくと共に, 発育促進作用の発現にとって極めて良好な反応条 件となって, 発育曲線でみられる lag phase の短 縮現象が出現したものと考えられよう。

このような発育促進作用を測定する反応系で は, “Metabolic factor” と “Growth factor” とが作用しており，両作用の協同作用と解釈す れば, “Growth factor”の検定法は，同時に “Metabolic factor”の力価を推定し得る可能性 を示唆するものと考えられる。

\section{Bioassay に用いる indicator について}

ビタミン，アミノ酸およびそれらの類縁物質の bioassay には，乳酸菌が広く用いられている。そ の理由として，(1) アミノ酸, ビタミンを要求 し, (2) 従って, その栄養要求がよく研究され, （3）その要求が特異的で，(4) 病原性がなく，(5) 乳酸を生成するために滴定法によっても定量でき る等の利点をあげることができる ${ }^{399}$ 。そのため に，多くの乳酸菌の bioassay に対する適用性が 検討された ${ }^{40,41}$ 結果，それぞれの被検物質に適し た乳酸菌を用いた bioassay が確立し，規格化さ れている19,39,42,43)。

たとえば，L． casei（ATCC-7469）によるリボ フラビン，葉酸その他 4 種のビタミン類扝よびア ラニン, アルギニン等のアミノ酸, Str. faecalis$\mathrm{R}$ (ATCC-8043) によるビタミン $\mathrm{B}_{6}$, ビオチン等 のビタミン類およびグルタミン酸, ヒスチジンそ の他 8 種のアミノ酸類の規格化された検定法があ る。ここで用いられた Str. faecalis- $\mathrm{R}$ は以前に Str. lactis-R として記載されていたもので，両者
は同一菌種であるとみなすことができる ${ }^{43)} 。$

一方，L. casei の発育を促進するペプタイド類 は前述のように, Strepogenin と総称され, Woolley らによってL. casei およびその他の乳酸菌を 用いた Strepogenin 活性の bioassay が報告され ている22,44-46)。

このように, bioassay において，その対象とな る物質は，生物的活性をもつものがす心゙て含まれ て打り，また，物質の添加によって現われる反応 は, 菌体自身の増殖, あるいは菌体内の生化学的 反応によって知ることができる。

本研究に执いて, 生物的活性を有する MF-fraction の bioassay のために 7 種の乳酸菌に対す る発育促進作用が測定され, 研究成績 1 で示され たそれぞれの乳酸菌の発育曲線が得られた。この 成績から，使用乳酸菌 7 種のらち，Str. lactis が MF-fraction 添加によって, 発育促進効果すなわ ち, 初期発育に最も著しい促進効果を示したこ と，および前述したように，Str. lactis は種々の 物質の bioassay に用いられていることからみて も，本研究に扔いて，MF-fraction の bioassay の ための indicator としてStr. lactis が用いられ たことは妥当と判断される。

\section{3. 試験管法としての濁度法について}

研究成績 $2.1 の$ 結果から, 培養 20 時間の場合, MF-fraction 添加濃度 $1 / 2$ の吸光度は0.110, 添加

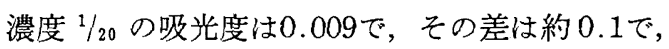
菌の発育程度にあまり差が認められない。しか し，培養29時間の場合の吸光度は，それぞれ0.740， 0.039で，その差は約0.7で，培養を 9 時間延長す ることによって, 吸光度で0.6の 差の増大を示し ており，発育程度に明確な差異が認められてい る。また, 図 6 から, $1 / 2$ と $1 / 20$ 濃度の吸光度の 值が直線性を示していることから，培養29時間で は，MF-fraction はここで添加した濃度の範囲内 で, Str. lactis に対して添加量にほぼ比例する值 で発育を促進しており，MF-fraction の検量線と して使用し得ることが認められる。

図 7 では，添加濃度 $1 / 20$ 以上では，注ぼ同程度 の直線的な傾向を示し，いずれも log phase に相 当し，さらに，培羕時間を延長した 48時間後の測 
定では，MF-fractionを高濃度に添加したもの は，stationary phase に達するため，各発育曲線 の平行性は失われている。したがって, 濁度法に よる MF-fraction の発育効果の検定は, 培養 20 時間から30時間に行なうのが適当であり，とく に，培養29時間後の測定が適していると認められ る。

\section{4. 試験管法としての酸度滴定法について}

乳酸菌の発育測定には，生成された酸をアルカ リで滴定し，消費したアルカリ量から求める間接 的な方法が広く用いられている ${ }^{19,39-43)}$ 。この場合 には操作がアルカリ滴定のため簡易化され，ま た, 培地の混濁や固形物の混入等によって測定が 阻げられない長所を持っている。

MF-fraction の検定にもこの方法をじゅうぶん 採り得ると考えられるので, N/10- $\mathrm{NaOH}$ による 滴定法が行なわれた。この場合は, 濁度法の場合 のように，等径の比色用試験管を用いる必要はな く，試料の添加量は $1.5 \mathrm{ml}$ でよい。

しかし，滴定の際に加熱して菌の発育を停止さ せたのち，生成した酸を直接試験管内で滴定を行 なうために，濁度法のように，同一試験管で，連 続した経時的測定を行ない，最適条件を求好るこ とはできない。したがって, 濁度法の結果から， 添加した MF-fraction の量によって, 発育の差 が最も著しく現われた29時間の培養時間を適用し たことは妥当であると思われる。

図 8 で示された酸度滴定法の結果から, 添加 MF-fraction の $1 / 8 \sim 1 / 2$ 濃度の範囲で，各測定值 はほぼ直線上に位置することが認められる。検定 範囲は, 前述の濁度法よりは幾分狭くなっている が，検量線として使用し得ることが認められる。

\section{Pulp-disk 法における 接種菌濃度の影響に วいて}

ビタミンおよびアミノ酸の微生物定量法の一つ として, pulp-disk 法が routine assay に適する 種々の利点を持つことはすでに知られている ${ }^{19,39}$, 42,43,47-51)。

研究成績2.3.1 2.3.8で得られた成績から， pulp-disk 法が MF-fraction の検定に適用し得る か否かについて，それぞれの検定条件について考
察する。

pulp-disk 法注, 研究方法2.3で述べられたよう に, pulp-disk 周辺に出現する菌の発育促進帯の 直径を計測して測定值とする。したがって，正確 な測定値を得るためには，発育促進帯の形状が問 題で, とくに発育促進帯周縁の境界線が, 明確に 判別できることが必要な第一条件である。

ビタミンやアミノ酸の pulp-disk 検定法では, 寒天平板に接種する菌濃度が，测定值に影響をお よぼす39,42,43,47,49-51)。すなわち，菌濃度が高くな るに従って, 発育促進帯は明確になるが, 試料の㹡 散が悪くなり直径が小さくなる傾向を示す。菌濃 度が低くなると，これと朔の傾向が見られる。

研究成績 2.3.1の結果でも，このような傾向が 認められている。培養20時間では, 接種菌濃度 1 および $1 / 2$ は, 平板全面に菌が発育するため, back ground と発育促進帯との判別がつかず, 逆 に, $1 / 50$ 以下の低濃度では，菌の発育が認められ ていない。このことから，菌濃度 $1 / 50$ 以下および $1 / 2$ 以上の 接種菌濃度は不適当と思われる。菌濃 度 $1 / 5$ および $1 / 10$ では，図 9-1)，2）で観察され たように，周縁部がまだ不明確であるが，発育促 進帯が出現し, さらに6 時間培養では, 図 9-3), 4）で観察されたように，全面に菌が発育して発 育促進帯との判別がつきにくくなる。この現象 は, 培養20時間から26時間までの間に, back ground の菌の発育が log phase に移行して, 急 激な発育を示したものと思われる。したがって, 寒天平板による pulp-disk 法では, 培養時間を比 較的悠密に設定する必要があると思われる。

以上の考察から, 接種菌濃度 $1 / 5$ 抒よび培養 20 時間が適当であると考えられる。

\section{Pulp-disk 法における寒天濃度の影響につ いて}

平板中の寒天濃度は, 試料物質の拡散に影響を およぼすものであり，一般に，寒天濃度およびゲ ル強度の増加に伴って，寒天ゲル内の拡散が悪く なり, 発育促進帯の直径は小さくなる傾向を示 す43,47,50,511。研究成績 2.3.2の結果でも, この傾 向が認められている。しかし, 周縁部の明確度に 差が認められなかったこと,および, $0.5 \%$ 濃度で 
は操作性に難点が認められたことから，寒天ゲル 内の搪散を可及的に増大させるためには $1 \%$ 前後 の寒天濃度が適当であると考えることができる。 しかし，寒天の種類によってゲル強度が相異して くることから，笽密には，ゲル強度を考慮した寒 天浱度を決定す心゙きである。

\section{Pulp-disk 法における食塩添加の影響につ} いて

寒天平板を用いた pulp-disk 法によって，抗生 物質の抗菌力を, disk 周辺の発育阻止帯の大小に よって検定する方法がある ${ }^{43,52-541}$ 。この場合，試 料物質の寒天培地中への搪散が悪く，菌の発育阻 止帯が明確に出現しないものでは，培地に食塩を 添加して菌の発育時間を延長させて，抗生物質の 拡散を助長する方法を採ることがある ${ }^{55-58)}$ 。本研 究において，研究成績2.3.1で述べたように，Str. lactis を接種した 検定用平板では，培養時間を延 長すると，平板全面に菌が発育し，一度出現した 発育促進带の判別が不可能になること，および， 適当な培養時間であっても，出現した発育促進帯 周縁部の境界線が不明確であること，などの点を 考虑して，研究成績2.3.3では，食塩の 添加量を 変化させた場合の，発育促進帯の形状が観察され ている。その結果から，食塩濃度を $1 \%$ 前後にす ることが適当であると考えることができる。

\section{Pulp-disk 法における氷室保存の 影響につ いて}

検定用平板上に出現する 発育促進帯周縁部の境 界線を，明確にするための検定条件の設定が第一 条件であることは前述したが，第二の 条件とし て，発育促進帯の直径を可及的に大きくすること も必要である。このことは，直径を計測する場合 の測定誤差を小さくすると同時に，試料の最小有 効濃度を低下させるために，検定範囲が広くな

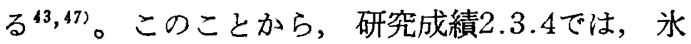
室保存したのち培養を行ない，出現した発育促進 帯の形状が観察されている。

その結果から， 2 時間程度の保存が 適当と思わ れる。

\section{Pulp-disk法における $\mathbf{p H}$ 指示薬添加の影 響について}

pulp-disk 周辺に出現する 発育促進帯拉よびそ の周辺には，Str. lactis の発育とともに，乳酸の 生成があり，当然その部位の $\mathrm{pH}$ 低下が考えら れる。したがって, 研究成績2.3.5は，検定用培 地に $\mathrm{pH}$ 指示薬を添加することによって，発育促 進帯と色調変化の両面加観察して，判別を容易 に, しかも正確な計測值が得られる可能性が考え られる。このことから，研究成績 2.3 .5 では検定 用培地に $\mathrm{pH}$ 指示薬を添加した場合の発育促進帯 の形状が観察された。

その結果, 発育促進帯の周辺に広がる不明確な 変色域が認められた。この現象は, MF-fraction と生成された乳酸の分子量の相異による拡散性の 難易に起因するものと思われる。すなわち, 分子 量の大きい MF-fractionの拡散に伴って菌の発育 促進帯が出現すると同時に，発育部位で乳酸が生 成される。ここで生成された乳酸は, MF-fraction に比較して，かなり分子量が小さいために，拡散 速度が大きく，したがって，菌の発育促進帯を中 心に広範な変色帯を形成したものと思われる。さ らに，測定条件を検討すれば，発育促進作用と同 時に，乳酸量をも測定し得る可能性が考えられ る。

\section{Pulp-disk 法における試料 pH の影響につ いて}

研究成績2.3.6では, MF-fraction の, 寒天ゲ ル内の拡散を助長することを目的として, 試料 $\mathrm{pH}$ を種々変化させた場合の, 発育促進帯の形状 が観察された。

この結果， $\mathrm{pH} 2.0$ から $\mathrm{pH} 4.8$ まで調製した 8 試料については, $\mathrm{pH}$ の上昇とともに発育促進帯 の直径が大きくなるが，その反面，不明確になる 傾向が認められており，一方， $\mathrm{pH} 2.0 \sim 4.4$ では 周縁部がかなり明確になっている。

したがって試料の $\mathrm{pH}$ を $\mathrm{pH} 2.0$ から $\mathrm{pH} 4.4$ までの間に調製することが適当であり，とくに， 直径を増大する意味で $\mathrm{pH} 4.4$ が最適であると考 えられる。

また, $\mathrm{pH} 5.0$ 以下の酸性側では発育促進帯が出 現したが， $\mathrm{pH}$ 6.0から pH 7.6では発育促進帯と いうよりは，むしろ，発育阻止帯が 出現してい 
る。この現象から，MF-fraction 中に存在する Str. lactis に対する発育促進物質は，酸性になる と, 寒天ゲル中への拡散性が良好であるが， $\mathrm{pH}$ 6.0 以上では急激に拡散性が低下し，発育阻止作 用が出現したものと考えられる。

\section{Pulp-disk 試料の乾燥の影響について}

本活性物質の凍結乾燥物は，極めて安定であっ て, 氷室に60日間保存しても，乳酸発酵促進作用

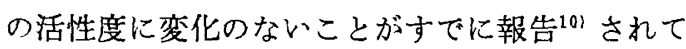
いる。研究成績2.3.7では, 試料溶液を disk に吸 収させたのち, 直ちに凍結乾燥して最高20日間氷 室保存した disk 試料を用いた場合の発育促進带 の形状が観察された。その結果，乾燥保存による 影響は全く認められず，乾燥状態での活性物質の 変性および分解等による失活がなかった。本研究 では，最大20日間の保存期間の検討にとどまった が，活性物質の安定性からみて，さらに保存期間 を延長し得る可能性が考えられる。

したがって，活性度の検定は，試料を調製した のち, 直ちに行なら必要はなく, 本研究結果の範 囲内で，20日以内の任意の時期に，測定し得ると 判断することができる。

\section{Pulp-disk 法における検量線について}

以上, pulp-disk 法の研究成績を検討した結果, 適当と思われる検定条件を設定することができ た。

研究成績2.3.8では，これらの検定条件下で，段 階希釈した MF-fractionを用いて，各濃度にお ける発育促進帯の直径を計測して, 図11のよ5な 成績が得られている。その結果, 試料濃度 $0.25 \sim$ $5.0 \mathrm{mg} / \mathrm{ml}(3.2 \mu \mathrm{g} \sim 63.8 \mu \mathrm{g} / \mathrm{disk})$ の籁囲の值が, 直線性を示していることから，この範团内で検量 線として適用し得ると考えられる。

\section{Pulp-disk 法と試験管法との比較について} 洘察3 12では，pulp-disk 法と試験管法の適用 性について検討され，いずれの方法も，検定法と して適用し得ると考えることができた。それぞれ の得られた検定範囲を比較すると，濁度法の最大 検定量は最小検定量の 10 倍, 酸度滴定法では 4 倍, pulp-disk 法では20倍を示している。このこ とから, pulp-disk 法が，もっとも検定範囲が広
く，しかも多数試料を任意の時期に測定し得るこ と，および培養時間の短縮などの点で適当である と考えることができる。

以上，考察1～13を総括すると，Str. lactis 用 いる試験管法および pulp-disk 法は, MF-fraction に対する bioassay として適用し得ることが認め られた。

さらに，唾液上清試料の前処理方法の簡易化等 によって, 本 bioassay の routine work として の有用性注，増大するものと考えられる。

このことは，実験室的な検定方法としてはもと より，臨床的な検定方法としても適用し得ること を示すものと考えられる。

\section{結論}

唾液中に含まれる酸産生菌代謝促進因子の活性 の測定方法の簡易化を目的として, 乳酸菌, とく に Str. lactis に対する発育促進作用を利用した bioassay の条件を検討し，次の結論を得た。

すなわち, 試験管法としての濁度法, 酸度滴定 法および平板法としての pulp-disk 法は, いずれ も，検定法として適用し得ることが認められた。

さらに, pulp·disk 法が，検定範囲，培養時間， 操作性, 展開性, 試料の安定性等の点で試験管法 より優れていることが認められた。

終りにのぞみ，終始ご指導，ご校閲を賜わった竹内光 春教授, ご指導いただいた川崎徽助教授（現，東京齿科 大学非常勤請師・東北歯科大学教授）ならびにご協力 をいただいた教室員各位に感謝する。

\section{引用文献}

1) Hartles, R. L. and Wasdell, M. R.: The metabolism of the oral flora VI. Preliminary observations on a water soluble factor in saliva which enhances the respiratory and glycolytic activity of the salivary flora, Brit. dent. J., 99 : 334-337, 1955.

2) Bramstedt, F., Kröncke, A. and Naujoks, R. : Über ein den anaeroben Kohlenhydratabbau aktivierendes Prinzip im menschlichen Speichel, Naturwissenschaften, $44: 331-332$, 1957.

3) Bramstedt, F., Kröncke, A. and Naujoks, R. : Über den Einfluss von fluor auf den Glukoseabbau isolierter Mundbakterienstämme, Odo- 
nt. Revy, 8 : 201-206, 1957.

4) Kröncke, A.: Ergebnisse und Probleme Biochemischer Speichelforschung, Dtsch. Zahnärzteblatt, 14 : 523-528, 1960.

5) Wasdell, M. R. : Manometric measurement of acid and gas production by the salivary flora, J. dent. Res., 39 : 1105 (Abstract), 1960.

6) Wasdell, M. R. : The effect of amino acids and related compounds on the metabolism of saliva, Arch. oral Biol., 7 : 25-38, 1962.

7) Beck, D. J. and Bibby, B. G. : Whole saliva, salivary sediment, and supernatant as fermenting agents for food, J. dent. Res., 40 : 479-485, 1961.

8）黒沢秋雄：混合唾液による炭水化物の酸産生に ついて(第 2 報)，歯科学報，61:149-150，1961.

9) Hartles, R. L. : Metabolic factors in saliva, J. dent. Res., 42 : 553-558, 1963.

10) Kawasaki, T.: On the activating factor in human saliva for acid fermentative bacterial metabolism, Bull. Tokyo dent. Coll , 5 : 2532, 1964.

11) Hay, D. I. and Hartles, R. L. : The effect of saliva on the metabolism of the oral flora, Arch. oral Biol., 10 : 485-498, 1965.

12) Hay, D. I. and Hartles, R. L. : Studies on the glycolytic-enhancing properties of human saliva, Arch. oral Biol., 11 : 337-347, 1966.

13) Guggenheim, B. : Über die Wirkung verschiedener Speichelfraktionen auf die Atmung von Mundbakterien, Helv. odont. Acta, 10 : supple. III, 59-93, 1966.

14) Mishiro, Y., Kirimura, K. and Ishihara, H. : Observations on the saliva factor that enhances the production of lactic acid by the oral flora, J. dent. Res., 45: 1824, 1966.

15）石原英夫：乳酸生成に対する唾液の作用につい て, 歯学, 54:320-334, 1967.

16) Molan, P. C. and Hartles, R. L. : Short communications; the identification of a glycolysis-enhancing factor in human parotid saliva, Arch. oral Biol., 14 : 421-426, 1969.

17) Kleinberg, I., Graw, D. and Komiyama, K. : Effect of salivary supernatant on the glycolytic activity of the bacteria in salivary sediment, Arch. oral Biol., 18: 787-798, 1973.

18) Holbrook, I. B. and Molan, P. C. : A further study of the factors enhancing glycolysis in human saliva, Arch. oral Biol., 18: 12751282, 1973.

19) 北原覚雄: 乳酸菌の研究, 東京大学出版会編, 東京, 1969, 243-286頁.

20) Woolley, D. W. : A new growth factor required by certain hemolytic Streptococci, J. Exp. Med., 73 : 487-491, 1941.

21) Feeney, R. E. and Strong, F. M. : Growth stimulating substances for Lactobacillus casei, J. Am. Chem. Soc., $64: 881-885,1942$.

22) Sprince, H. and Woolley D. W. : Relationship of a new growth factor required by certain hemolytic Streptococci to growth phenomena in other bacteria, J. Exp. Med., 80 : 213-217, 1944.

23) Woolley, D. W. : Observations on the growth-stimulating action of certain proteins added to protein-free diets compounded with amino acids, J. Biol. Chem., 159 : 753-754, 1945.

24) Woolley, D. W. : Some correlation of growth-promoting powers of proteins with their Strepogenin content, J. Biol. Chem., 162 : 383-388, 1946.

25) Woolley, D. W. : Strepogenin activity of derivatives of glutamic acid, J. Biol. Chem., 172 : 71-81, 1948.

26) Stockes, J. L., et al. : Factors affecting the rate of growth of Lactobacillus casei, J. Biol. Chem., 178 : 93-101, 1949.

27) Wright, L. D., et al.: An improved assay for "Streptogenin" based on essential nature of material for Lactobacillus bulgaricus Proc. Soc. Exp. Biol. Med., 74 : 687-690, 1950.

28) Merrifield, R. B. and Woolley, D. W. : The isolation and determination of structure of peptides with Strepogenin activity. 1. Serylhistidylleucylvalylglutamic acid and Serylhistidylleucylvalylglutamylalanylleucine from insulin, J. Am. Chem. Soc., 78 : 358-362. 1956.

29) Woolley, D. W. and Merrifield, R. B. : Anomalies of the structural specificity of peptides, Ann. New York Acad. Sci., 104 : 161$171,1963$.

30）三代幸彦ほか：Streptococcus salivarius の乳 酸産生を促進する唾液透析外液因子の性状，歯 基礎誌, $11: 24-29,1969$.

31) Kirimura, K., Morita, M. and Mishiro, Y. : Effect of protein hydrolysates on the fermentative activity of streptococcus salivarius, J. dent. Res., 49:890, 1970.

32) Mishiro, Y., Morita, M. and Kirimura, K. Promoting effect of saliva dialyzate on the lactate production of Streptococcus salivarius, Arch. oral Biol,, 15 : 465-467, 1970.

33）小山登志江ほか：微生物の乳酸産生に対する牛 血清アルブミン部分水解物の促進効果, 歯学, 59 : 265-269, 1971. 
34）森永和男：唾液タンパク部分水解物の乳酸䣨酵 促進効果，歯基礎誌，15:187-205，1973.

35) Melville, T. H. and Hartles, R. L. : A preliminary study of the effect of saliva supernatant on the glycolytic activity of a pure culture of a streptococcus, Arch. oral Biol., 11 : 877-882, 1966.

36）守屋寛：ゲル滤過法, 広川化学シリーズ5, 広 川畫店, 東京, 1966.

37) Roberts, E. C. and Snell, E. E. : An improved medium for microbiological assays with Lactobacillus casei, J. Biol. Chem., 163 : 499-509, 1946.

38）川崎徹ほか：唾液中に含まれる䁔酸性菌の代謝 促進因子の乳酸菌に対寸る発育促進作用（II）， 歯科学報, $69: 852-853,1969$.

39）角田俊直：微生物によるアミノ酸の定量法, 蛋 白質化学 I, 赤堀四郎他編集, 共立出版, 東京, 1952，282-329.

40）田村学造ほか：乳酸菌によるアミノ酸定量法 (その 1 ) 乳酸菌のアミノ酸要求並びにアミノ酸 標準曲線の作成, 農化，26:464-470，1952.

41）田村学造ほか：乳酸菌によるアミノ酸の定量法 (その 2 ) カゼインのアミノ酸含量の定量, 農化, 26 : 474-476, 1952.

42）杉村敬一郎，宮沢滋：微生物によるアミノ酸お よびビタミンB群の定量法, 実験化学講座25, 生物化学III, 日本化学会編, 東京, 1958, 265307頁.

43）岩井和夫：マイクロバイオアッセイ，基礎分析 化学講座 29 , 日本分析化学会編, 共立出版, 1965

44) Wright, L. D. and Skegges, H. R.: The growth factor requirements of certain Streptococci, J. Bacteriol, 48 : 117-118, 1944.

45) Anderson, A. W. and Elliker, P. R. : The nutritional requirements of lactic Streptococci isolated from starter cultures. II. A stimulatory factor required for rapid growth of some strains in reconstituted nonfat milk solids, J. Dairy Sci., 36 : 608-613, 1953.

46) Kizer, D. E., et al. : Stimulation of lactic acid bacteria by substances concomitant to certain proteolytic enzymes, J. Dairy Sci., 38 : 303-308, 1955.

47）小嶋尚夫ほか：Pulp disc 法によるビタミン及 びアミノ酸の微生物定量法（第 1 報）数種のB 群ビタミンの定量について（その1），農化，32： 33-37，1957.

48）小嶋尚夫, 松谷豊 : Pulp disc 法によるビタミ ン及びアミノ酸の微生物定量法 (第2 報) 数種 のB群ビタミンの定量について（その 2 ), 農化 $32: 38-42,1957$.

49）小嶋尚夫，松谷豊：Pulp disc 法によるビタミ ン及びアミノ酸の微生物定量法（第3 報）ビ夕 ミン及びアミノ酸の標準曲線の作成, 農化, 32 : 100-106, 1957.

50）松谷豊, 小嶋尚夫：Pulp disc 法によるビタミ ン及びアミノ酸の微生物定量法（第 4 報）数種 のアミノ酸の定量について, 農化, 32 : 106-110, 1957.

51）小嶋尚夫，松谷豊：Pulp disc 法によるビタミ ン及びアミノ酸の微生物定量法 (第 5 報) ビタ ミン及びアミノ酸の迅速定量について，農化， 32 : 189-192, 1957.

52）住木諭介：抗生物質, 上巻, 東京大学出版会, 1961.

53）梅沢純夫：抗菌性物質, 培風館, 1963.

54）芝茂, 田口鉄男編集：マイトマイシンの基 礎上臨床, 医学書院，1967，20-32頁.

55) Foster, J. W. and Woodruff, H. B. : Microbiological aspects of Streptothricin. II . Antibiotic activity of Streptothricin, Arch. Biochem., 3 : 241-255, 1943.

56) Loo, Y. H., et al.: Assay of Streptomycin by the paper-disc plate method, J. Bacteriol., 50 : 701-709, 1945.

57) Klein, M. and Kimmelman, L. J. : The role of spontaneous variants in the acquisition of Streptomycin resistance by the shigellae, J. Bacteriol., 52 : 471-479, 1946.

58) Berkman, S., Henry, R. J. and Housewright, R. D. : Studies on Streptomycin. 1. Factors influencing the activity of Streptomycin, J. Bacteriol., 53 : 567-574, 1947. 


\section{Abstract: Bioassay of Metabolic Promoting Factor in Human Saliva for Acidogenic}

Bacteria. Fumie AMANO*. When the human whole saliva is fractionated by centrifugation into supernatant and sediment, the latter contains oral bacteria in addition to other insoluble materials. The respiration and lactic acid fermentation of the sediment are enhanced by the addition of the supernatant, and the substance responsible for this stimulatory effect was called the metabolic factor by Hartles and others. Although studies on the chemical nature of the factor have revealed that it may not be a single chemical compound but is probably active as a multicomponent system consisting of proteins, peptides and amino acids, the reaction mechanism and detailed chemical nature of the components remain unclear. On the other hand, the assay of the metabolic factor has been carried out manometrically by means of Warburg thechnique using the salivary sediment as the source of bacteria to determine the oxygen consumption directly and the lactate production indirectly as $\mathrm{CO}_{2}$ evolved from a $\mathrm{CO}_{2}$ bicarbonate buffer. This method, however, is not suitable for assaying a large number of samples for a short period because of its rather complicated and time-consuming procedures. In addition, the use of salivary sediment as the source of bacteria does not always give reproducible results.

In the present study, methods were explored which can be used in a mass examination. The substances in the salivary supernatant were fractionated on a column of Sephadex gel, and each fraction was assayed by the method described above for the stimulatory activity in organic acid production. The fractions with a high activity were combined and used as the fraction of the metabolic factor. The active fraction was found to promote the initial growth of several strains of bacteria tested, particularly that of Streptococcus lactis. Thus, this strain was selected and used as the test material instead of the snlivary sediment. The activity of the metabolic factor was then assayed by a turbidometry, a titration method and by a pulp-disk method on agar-plate. The experimental conditions were studied for a pulp-disk method.

All the three methods examined were found to be satisfactory. Among these pulp-disk method was fonud to be better than the other methods. It was concluded that the pulp-disk method established may be used routinely for the purpose of examination in a large scale. 